Published in "Marine Geology 282(1-2): 1-4, 2011"

which should be cited to refer to this work.

\title{
Carbonate mounds in shallow and deep time
}

\author{
J.-P. Henriet ${ }^{\text {a,* }}$, S. Spezzaferri ${ }^{\text {b }}$, E. Samankassou ${ }^{c}$, A. Foubert ${ }^{\text {d }}$, D. Van Rooij ${ }^{\text {a }}$, A. Rüggeberg a,d \\ a Renard Centre of Marine Geology, Ghent University, Krijgslaan 281, S8, B-9000 Gent, Belgium \\ ${ }^{\mathrm{b}}$ Department of Geosciences, University of Fribourg, Chemin du Musée 6, CH-1700 Fribourg, Switzerland \\ ' Section of Earth and Environmental Sciences, University of Geneva, Rue des Maraîchers 13, CH-1205 Geneva, Switzerland \\ d Department of Earth and Environmental Sciences, K.U. Leuven, Celestijnenlaan 200 E, B-3001 Heverlee, Belgium
}

Over a decade of research on recent cold-water coral mounds in various oceans has set the stage for comparative studies between recent and ancient carbonate mound systems, with the aim to unravel generic processes and reveal the "red thread" in a fundamental strategy of Life building Geology - a strategy nearly as ancient as Life itself. Natural laboratories have been identified in the present ocean, which provide new insights in oceanographic controls on species migration and settlement, in the interaction of currents and carbonate build-up, in the earliest diagenesis which overprints environmental signals and shapes the template of compartmentalization of carbonate build-ups, and in so many other processes and factors ultimately shaping carbonate bodies, comparable in size and properties to the large-scale carbonate hydrocarbon reservoirs in the geological record. Ocean drilling and coring is an essential component of this research.

Ideally, this process is a two-way avenue between Shallow and Deep Time, where fundamental and industrial knowledge about fossil carbonate mounds can drive further investigations and even experimentation in the present seas, while the discoveries and process studies on "live" systems can yield new insights in the architecture and evolution of ancient reservoir systems. This bridging exercise is the quintessence of COCARDE (Cold-Water Carbonate Reservoir Systems in Deep Environments), an international network under the auspices of IOC-UNESCO (http://www.cocarde.eu). COCARDE has organised two workshops in 2009, with a significant support of European programmes (e.g. ESF Magellan workshop series) and partner projects (e.g. ESF EuroDIVERSITY project MiCROSYSTEMS). This special issue groups 12 papers, all addressing observations which by their nature have the potential to provide keys to generic processes, of relevance for past carbonate systems. As COCARDE proceeds, it is the objective to "reciprocate" in near future with an equivalent grouping of contributions from the study of fossil studies, to guide further research in the present ocean. It is the purpose of COCARDE to strengthen such a reflux from the studies of fossil systems by stimulating relevant continental drilling exercises, with comparable sampling protocols, resolution and analytical procedures where relevant - to allow direct comparisons with records from ocean drilling.

The papers in this special issue have been structured in four themes: (i) keys to palaeoenvironmental control, (ii) mound initiation, growth and demise, (iii) of microbes and mounds, and (iv) tracking organominerals Recent and Ancient.

\section{Introduction: carbonate mounds in shallow and deep time}

A decade ago, at the Hanse 2000 Conference on Ocean Margin Systems in Delmenhorst near Bremen in Germany, it was reported that the seismic exploration and the systematic bathymetric surveying of ocean margins increasingly brought evidence of large clusters of giant, cold-water coral mounds, down to $1000 \mathrm{~m}$ depth. It was proposed that the detailed, curiosity-driven research on sub-recent mounds might yield new views on old mounds (Henriet et al., 2002). Carbonate mound

\footnotetext{
* Corresponding author.

E-mail address: jeanpierre.henriet@ugent.be (J.-P. Henriet).
}

building is indeed a recurrent, yet poorly understood strategy of Life throughout Phanerozoic times.

Concurrently, it was stated: there is however still a long way to go before the research worlds of ancient and modern mounds can be bridged. Petrologists and palaeontologists of ancient mounds on one side, and geophysicists and oceanographers studying recent mound settings on the other side form two communities, speaking a different language, and for whom in addition the dialogue with microbiologists is some kind of a challenge. Taking the challenge involves the definition of a common strategy, where the new exploratory power and holistic view of geophysics on full mound systems in their natural oceanic environment will pave the way to targeted sampling opportunities, and new analytical breakthroughs. ...Last but not least, such strategy bears the potential of 
an exciting international educational exercise, which can reveal to students (of any age) how Earth and Life, Geosphere and Biosphere may have interacted throughout Phanerozoic times, and still interact in a most spectacular way.

In January 2009, the ESF Magellan Workshop COCARDE (ColdWater Carbonate Reservoir Systems in Deep Environments) in Fribourg, Switzerland, endeavoured not only to bridge the gap between the above mentioned research worlds of ancient and modern mounds, but also to target an additional community: the hydrocarbon industry. Meanwhile, IODP Expedition 307 on Challenger Mound in Porcupine Seabight off Ireland had drilled and sampled in detail a full mound section (Ferdelman et al., 2006; Kano et al., 2007; Foubert and Henriet, 2009), IOC-UNESCO had launched the Geosphere-Biosphere Coupling processes (GBCP) programme with a focus on capacity building around mound research, mound scientists had teamed up in projects like CARBONATE (ESF EuroMARC - Carbonate mound drilling at mid-latitudes) and with microbiologists in MiCROSYSTEMS (ESF EuroDIVERSITY - Microbial Diversity and Functionality in Cold-water Coral Ecosystems) and microbialites were found to form a substantial component... of sub-recent tropical reefs (IODP Tahiti Exp. 310, ESF EuroMARC project CHECREEF)!

MiCROSYSTEMS, COCARDE and CHECREEF teamed up under the auspices of ESF and IOC-UNESCO in September 2009 to organise the "Carbonate mounds in Shallow and Deep time" workshop and field seminar based in Oviedo, Asturias, Spain. At that workshop, Philippe Lapointe (TOTAL E\&P) summarised the newly identified industrial interest in mounds. In early times of hydrocarbon exploration, the potential of carbonate mounds as reservoirs had not readily been identified. On a background of new discoveries of giant hydrocarbon accumulations, the confrontation with the modern world - in particular revealed by ocean drilling - becomes an eye opener and spurs new exploration insights and strategies. The comprehension of the importance of carbonate mound systems as hydrocarbon reservoirs passes through the understanding of the fundamental processes of mound initiation, growth and demise, and through the identification of plausible sizes, geometries, basin settings and controls. The diversity of carbonate mound systems in the sub-recent world is a key to the diversity of mound settings, morphologies and characteristics in deep time. The comparative analysis of mound evolution in the recent and ancient world fuels new insights in reservoir plumbing systems and spurs improvements in reservoir prediction. Early to late diagenetic processes, products and patterns stand as central themes. A key strategy within COCARDE is the drilling of both subrecent and ancient carbonate mounds, from both warm- and cold-water carbonate factories. This implies (1) the move towards integrated oceanic and continental scientific drilling exercises (IODP/ICDP), (2) the convergence of logging, sampling and analytical protocols and (3) the objective of achieving a comparable resolution.

\section{Keys to palaeoenvironmental control}

Over a hundred of oceanographic cruises in the past decade, many of them in the framework of large-scale European projects like HERMES and HERMIONE, have generated an unprecedented knowledge about the setting of sub-recent carbonate mounds and about environmental controls on cold-water coral ecosystems.

As summarised by the "Palaeoenvironment" panel in Fribourg, carbonate mounds provide unique archives, and the understanding of the entire architecture of a mound is fundamental in the identification of past environmental changes. Recent carbonate mounds stand as natural laboratories to link the build-up history and architecture to high-resolution sequence stratigraphy. Several studies in recent years have described environmental parameters controlling the growth and development of cold-water coral carbonate mounds on the North-east Atlantic continental margin (De Mol et al., 2002; Dorschel et al., 2005; Rüggeberg et al., 2005; Dorschel et al., 2007; Rüggeberg et al., 2007;
Van Rooij et al., 2007; Huvenne et al., 2009; Margreth et al., 2009; Mienis et al., 2009; Van Rooij et al., 2009, among others).

In this special issue, Rüggeberg et al. (this volume) provide a detailed description of water masses and sill dynamics in a thriving, sub-polar cold-water coral reef system in northern Norway. Coldwater corals such as Lophelia pertusa form an essential component of sub-recent carbonate mounds, and it is crucial to unravel their diagnostic value for environmental controls such as seawater temperature and salinity, and hence density. The CTD measurements and related observations in the shallow Stjernsund setting provide additional evidence of the validity of the Dullo et al. (2008) hypothesis, which links the occurrence of thriving cold-water corals in the North-east Atlantic to an isopycnal surface $\left(27.5 \mathrm{~kg} \mathrm{~m}^{-3}\right)$, bounding major water masses.

An essential characteristic of the giant carbonate mounds off Ireland is that more than $50 \%$ of the mound volume is of terrigenic origin. $\mathrm{Sr}$ - and $\mathrm{Nd}$-isotopic fingerprinting on terrigenic fractions in a gravity core allowed Pirlet et al. (this volume) to identify Ireland as the main source of terrigenic material in Challenger Mound, with in addition some volcanic material from northern volcanic provinces, transported during cold climatic stages. Smectite signals are attributed to the initial stage of continental chemical weathering, following glacial retreat. The synchronous lack of coral growth emphasises the impact of the deglaciation of the British-Irish ice sheets on mound growth on glacial margins.

In a totally different setting, on top of mud volcanoes in the Western Alboran Basin in water depths of some $400 \mathrm{~m}$ in the Mediterranean, Margreth et al. (this volume) investigated through gravity coring the environmental message from planktonic and benthic foraminiferal assemblages, associated with two distinct phases of cold-water coral growth between 16000 and 2000 years BP. They observed shifts in planktonic foraminiferal assemblages, associated with the growth and decline of the coral ecosystems, and tentatively linked these to palaeoclimatic changes and an early human impact on the shores of the Mediterranean.

\section{Mound initiation, growth and demise}

Through the coring of carbonate mounds, and in particular the fullmound drilling exercise of IODP Exp. 307 on Challenger Mound off Ireland, we increasingly can confront present oceanic and ecosystem dynamics with the unique palaeoenvironmental record, locked in giant carbonate mounds. The discovery of numerous clusters of small mounds on the recent seabed, both on the shelf edge and in the depth range of the deep, giant carbonate mound provinces, fuels the debate on potential recent analogues for the initial phase of mound building.

De Mol et al. (this volume) compare shallow water versus deepand cold-water coral habitats in the Bay of Biscay. On the shelf edge, between $260 \mathrm{~m}$ and $350 \mathrm{~m}$, numerous small mounds up to $5 \mathrm{~m}$ high are covered by cold-water coral rubble. Interestingly, as observed in a box-core, the rubble is superficial, hence the coral settled on a preexisting, non-biogenic sedimentary morphology, a setting reminding of the Darwin mounds in Rockall Trough (Masson et al., 2003). In deeper waters, between 700 and $950 \mathrm{~m}$, both living and dead coldwater corals colonise spurs, cliffs and overhangs in canyons. The depth of these refuges is again in coherence with the hypothesis of Dullo et al. (2008) concerning a seawater density control.

Mini-mounds in Porcupine Seabight are described in a twin contribution by Wheeler et al. (this volume) and Foubert et al. (this volume) The Moira mounds are located in water depths between 800 and $1100 \mathrm{~m}$, in the middle of a province of giant carbonate mounds the Belgica mound province. Wheeler et al. (this volume) provide an exhaustive analysis of the sedimentary environment and processes and argue that the Moira mounds might illustrate an early stage growth phase for future, giant cold-water coral mounds. The morphological setting of the Moira mounds, topping a spectacular 
sedimentary wave field, is strikingly illustrated by a ROV-borne microbathymetry and video survey (Foubert et al., this volume). This setting highlights the importance of strong (tidal) currents in the competition between cold-water coral growth and sedimentation in mound provinces.

Raddatz et al. (this volume) report on a detailed analysis of the basal interval of the $155 \mathrm{~m}$ high Challenger Mound, drilled by IODP Exp. 307. The mound initiation and start-up phase coincide with the intensification of the Northern Hemisphere Glaciation at around 2.7 Ma. Stable oxygen and carbon isotope records and sortable silt analysis document the initial setting of cold-water corals and the impact of intermediate water masses of southern origin (Mediterranean and Bay of Biscay). Enhanced flow conditions led to erosion intervals, during which early diagenetic processes could overprint geochemical signals. The dissolution of coral skeletons and the formation of gypsum, pyrite and dolomite in those basal intervals display a striking similarity with the processes described by Pirlet et al. (2010) on top of Mound Perseverance, further west in Porcupine Seabight.

\section{Of microbes and mounds}

In the recent decade, microbial populations have been detected in environments, supposed for long to be hostile. It is a major outcome of the Integrated Ocean Drilling Program to have demonstrated that the deep sea and the deep subsurface of the Earth change the ideas on the limits of life on Earth drastically and open the view to a largely unknown and unexplored microbial biosphere on our planet: the Deep Biosphere. IODP Exp. 307 had set up a hybrid core flow, merging microbiological and biogeochemical procedures and protocols with those, meeting the standards of palaeoenvironmental work. Though it was demonstrated that carbonate mounds and their substrate may represent a significant prokaryotic sub-seafloor habitat (Webster et al., 2009), a direct link between microbial processes and the genesis and growth of recent coldwater coral mounds could not be straightforwardly elucidated yet. In this volume, Mangelsdorf et al. (this volume) study molecular indicators for the distribution of present and past microbial communities in sample material within and below Challenger Mound and from an upslope reference site. In general, the biomarker data show lower abundance of past microbial communities in the mound section compared to the sediments below the mound base and from the reference site. Biomarkers for living microbial populations were not detected in the mound sequence, which is in coherence with relatively low cell count data (Ferdelman et al., 2006). Methane, ethane and propane were detected below the mound. Gas wetness data point to a mixed gas of biogenic and thermogenic origin, with a higher proportion of the biogenic component.

Challenger Mound, drilled in Exp. 307, forms part of the Belgica mound province, which is already partly in the burial stage. This was the rationale of moving to the Gulf of Cadiz off Northwest Morocco, where a set of carbonate mounds had been discovered in 2002 in a province of active fluid flow, in close spatial relationship with giant mud volcanoes (Van Rensbergen et al., 2005). Van Rooij et al. (this volume) set the stage of the study of the cold-water coral mounds on the Pen Duick Escarpment in the framework of the MiCROSYSTEMS project. This multidisciplinary study integrates geophysical, sedimentological, oceanographic, biogeochemical and microbiological data towards a holistic view on the interaction of both environmental and geological drivers in cold-water coral mound development. Highresolution reflection seismic data document possible migration pathways of methane to the escarpment, as evidenced by seeprelated authigenic carbonate crusts. In contrast to the North-Atlantic mound provinces, no living corals could be spotted on the mounds, which however feature thick plates of open coral rubble.

The biogeochemical processes, microbial community composition and diagenetic history of three cold-water coral mounds located in close proximity to each other on the Pen Duick Escarpment - the Pen
Duick Alpha, Beta and Gamma Mounds - are reported by Wehrmann et al. (this volume) and Templer et al. (this volume). Alpha and Beta Mounds feature a shallow sulphate-methane transition zone (SMTZ) with increased sulphate reduction rates indicating the presence of microbially mediated anaerobic oxidation of methane (AOM). A diverse microbial community of prokaryotes was identified, which has been previously described in a range of different environments such as hydrothermal vent sites, hypersaline environments, biogas reactors and soils, but which shows no significant similarity with communities documented in Challenger Mound (Templer et al., this volume). Hydrogen sulphide produced during sulphate reduction coupled to the anaerobic oxidation of methane diffuses upward and induces aragonite dissolution, as evidenced by strongly corroded corals in Alpha Mound. This mound has been affected by strong fluctuations in the depth of the SMTZ. In Gamma Mound, which lacks a shallow SMTZ, organic matter mineralization is driven by dissimilatory iron reduction and organoclastic sulphate reduction coupled to oxidative sulphur cycling (Wehrmann et al., this volume).

\section{Tracking organominerals - modern and ancient}

As developed by Stéphanie Larmagnat (Université Laval, Québec) at the Oviedo workshop, the main textural attribute of ancient, spongerich carbonate mudmounds is the so-called polymud fabric. Our current understanding of the polymud fabric considers organomineralization as a key process. Larmagnat and Neuweiler (this volume) report on the organomineral lithification approach, exploring sediment cores from Alpha, Beta and Gamma Mounds on the Pen Duick Escarpment for their potential to drive an organomineralization process in analogy with Phanerozoic sponge-rich carbonate mudmounds. The potential for induced-and-supported organomineralization (ISOM) in Atlantic coral mounds is tracked by peak patterns of fluorescent dissolved organic matter (FDOM) present in pore waters down to $3 \mathrm{~m}$ in Gamma Mound sediment. Permineralizing fluids that are characteristic for ISOM are locally present within the shallow subsurface, but no ISOM-related authigenic carbonate was observed. Both the lack of organic substrates that is due to the absence of degrading connective tissues from a cryptic community and the high amount of infiltrated mud that acts as a sorbent on the sampled site might explain the absence of ISOM in Gamma Mound. The labyrinthine deposits of coral rubble or current swept coral mounds however, spectacularly illustrated in Van Rooij et al. (this volume, Fig. 7) are prone to host a sponge-rich cryptic community and therefore, in their deeper parts, should provide a variety of substrates for ISOM during suboxic cycling of natural organic matter.

\section{Conclusions and forward look}

The contributions in this volume document the direct approach to move from Shallow to Deep Time in carbonate mound research. The expertise gained in a decade of oceanic research and in various natural laboratories, developed on accessible sites along the Atlantic and Mediterranean margins, allows the identification of processes and strategies which can yield new insights in the carbonate mound "factories" of the past. The application of up-to-date analytical methods on drilled sample material from sub-recent mounds makes it possible to reconstruct environmental control parameters, from mound initiation to the present day. However, as discussed at the Oviedo workshop, there are some limitations in the use of proxies such as stable isotopes, element ratios, faunal assemblages and grainsize parameters to reconstruct the palaeoenvironment of ancient carbonate mounds. The limiting factors may be related to evolutionary faunal changes, as well as to compaction of sediments and diagenetic overprint (temperature and pressure increase, impact of fluids and brines). At the Oviedo workshop, some proxies used to reconstruct the palaeoenvironment of sub-recent mounds have been described and discussed in terms of their potential for reconstructions 
in Deep Time. The paramount importance of palaeoceanographic reconstructions in both fundamental and applied studies has been stressed, but it is recognised that both methods and tools may need substantial changes when addressing old geological settings. The overall recommendation was to move backwards in time in discrete steps. The modern coral-rich mound system, which by itself appears diverse and with a variety of controlling factors, moreover offers an excellent potential to drive induced-and-supported organomineralization and to share a crucial process of early diagenesis with Phanerozoic sponge-rich carbonate mudmounds. The diversity and role of sponge communities in recent cold-water coral mounds is the subject of ongoing PhD work, and the convergence of these research tracks offers promising perspectives.

What is now being developed in parallel within COCARDE is the inverse approach, tackling selected carbonate mound systems in Deep Time with the insights and strategies, gained from modern carbonate mound research. Successes achieved with ocean drilling in the modern ocean have now to be matched by initiatives in continental drilling, by the same or similar teams, with the same or similar protocols, as far as relevant. First targets have been identified at the Oviedo workshop, and proposals move forward into the ICDP scheme.

It is the convergence of these two tracks, and the iteration between observations in Shallow and Deep Time, that will spark new ideas and concepts in this theme of prime fundamental and applied importance.

\section{Acknowledgements}

The COCARDE (Cold-water Carbonate Reservoir Systems in Deep Environments) initiative is funded by the Fund for Scientific ResearchFlanders (FWO-Vlaanderen) within the International Co-ordination Action scheme and under the auspices of IOC-UNESCO. The Fribourg COCARDE Workshop was funded by the ESF Magellan scheme. The Oviedo workshop "Carbonate mounds in Shallow and Deep Time" was funded by the ESF EuroDIVERSITY programme (MiCROSYSTEMS) and further supported by the ESF EuroMARC programme (CHECREEF) and the University of Oviedo, Asturias, Spain. Beyond the sponsors acknowledged in the relevant papers of this issue, the authors wish to acknowledge the significant role of IODP in advancing modern carbonate mound science, through Expedition 307. The editors acknowledge the reviewers who provided insightful improvements to the manuscripts submitted for this issue of Marine Geology.

\section{References}

De Mol, B., Van Rensbergen, P., Pillen, S., Van Herreweghe, K., Van Rooij, D., McDonnell, A., Huvenne, V., Ivanov, M., Swennen, R., Henriet, J.P., 2002. Large deep-water coral banks in the Porcupine Basin, southwest of Ireland. Marine Geology 188, 193-231.

Dorschel, B., Hebbeln, D., Rüggeberg, A., Dullo, W.-C., Freiwald, A., 2005. Growth and erosion of a cold-water coral covered carbonate mound in the Northeast Atlantic during the Late Pleistocene and Holocene. Earth and Planetary Science Letters 233, $33-44$.
Dorschel, B., Hebbeln, D., Rüggeberg, A., Dullo, C., 2007. Carbonate budget of a deep water coral mound: Propeller Mound, Porcupine Seabight. International Journal of Earth Sciences 96, 73-83.

Dullo, W.-C., Flögel, S., Rüggeberg, A., 2008. Cold-water coral growth in relation to the hydrography of the Celtic and Nordic European continental margin. Marine Ecology Progress Series 371, 165-176.

Ferdelman, T.G. Kano, A., Williams, T., The IODP Expedition 307 Scientists, 2006. IODP expedition 307 drills cold-water coral mound along the irish Continental margin. Scientific Drilling 2. doi:10.2204/iodp.sd.2.02.2006. March 2006.

Foubert, A., Henriet, J.-P., 2009. Nature and significance of the recent carbonate mound record. Lecture Notes in Earth Sciences, 126. Springer-Verlag, Berlin, Heidelberg, p. 298. doi:10.1007/978-3-642-00290-8. 3 .

Henriet, J.P., Guidard, S., the ODP “Proposal 573" Team, 2002. Carbonate mounds as a possible example for microbial activity in geological processes. In: Wefer, G., Billett, D., Hebbeln, D., Jørgensen, B.B., Schlüter, M., Weering, T.v. (Eds.), Ocean Margin Systems. Springer Verlag, Berlin, Heidelberg, New York, pp. 437-455.

Huvenne, V.A.I., Van Rooij, D., De Mol, B., Thierens, M., O'Donnell, R., Foubert, A., 2009. Sediment dynamics and palaeo-environmental context at key stages in the challenger cold-water coral mound formation: clues from sediment deposits at the mound base. Deep Sea Research I 56, 2263-2280.

Kano, A., Ferdelman, T.G., Williams, T., Henriet, J.-P., Ishikawa, T., Kawagoe, N., Takashima, C., Kakizaki, Y., Abe, K., Sakai, S., Browning, E.L., Li, X., Scientists, I.O.D.P.E., 2007. Age constraints on the origin and growth history of a deep-water coral mound in the northeast Atlantic drilled during Integrated Ocean Drilling Program Expedition 307. Geology 35, 1051-1054.

Margreth, S., Rüggeberg, A., Spezzaferri, S., 2009. Benthic foraminifera as bioindicator for cold-water coral reef ecosystems along the Irish margin. Deep-Sea Research I 56, 2216-2234.

Masson, D.G., Bett, B.J., Billett, D.S.M., Jacobs, C.L., Wheeler, A.J., Wynn, R.B., 2003. The origin of deep-water, coral-topped mounds in the northern Rockall Trough, Northeast Atlantic. Marine Geology 194, 159-180.

Mienis, F., van den Land, C., de Stigter, H.C., van den Vorstenbosch, M., de Haas, H., Richter, T., van Weering, T.C.E., 2009. Sediment accumulation on a cold-water carbonate mound at the Southwest Rockall Trough margin. Marine Geology 265, 40-50.

Pirlet, H., Wehrmann, L.M., Brunner, B., Frank, N., DeWanckele, J., Van Rooij, D., Foubert, A., Swennen, R., Naudts, L., Boone, M., Cnudde, V., Henriet, J.-P., 2010. Diagenetic formation of gypsum and dolomite in a cold-water coral mound in the Porcupine Seabight, off Ireland. Sedimentology 57, 786-805.

Rüggeberg, A., Dorschel, B., Dullo, W.-C., Hebbeln, D., 2005. Sedimentary patterns in the vicinity of a carbonate mound in the Hovland Mound province, northern Porcupine Seabight. In: Freiwald, A., Roberts, J.M. (Eds.), Cold-water Corals and Ecosystems. Springer-Verlag, Berlin, Heidelberg, New York, pp. 87-112.

Rüggeberg, A., Dullo, C., Dorschel, B., Hebbeln, D., 2007. Environmental changes and growth history of Propeller Mound, Porcupine Seabight: evidence from benthic foraminiferal assemblages. International Journal of Earth Sciences 96, 57-72.

Van Rensbergen, P., Depreiter, D., Pannemans, B., Moerkerke, G., Rooij, D.V., Marsset, B., Akhmanov, G., Blinova, V., Ivanov, M., Rachidi, M., Magalhaes, V., Pinheiro, L., Cunha, M., Henriet, J.-P., 2005. The El Arraiche mud volcano field at the Moroccan Atlantic slope, Gulf of Cadiz. Marine Geology 219, 1-17.

Van Rooij, D., Blamart, D., Richter, T., Wheeler, A., Kozachenko, M., Henriet, J.-P., 2007. Quaternary sediment dynamics in the Belgica mound province, Porcupine Seabight: ice-rafting events and contour current processes. International Journal of Earth Sciences 96, 121-140.

Van Rooij, D., Huvenne, V.A.I., Blamart, D., Henriet, J.-P., Wheeler, A., de Haas, H., 2009. The Enya mounds: a lost mound-drift competition. International Journal of Earth Sciences 98, 849-863.

Webster, G., Blazejak, A., Cragg, B.A., Schippers, A., Sass, H., Rinna, J., Tang, X., Mathes, F., Ferdelman, T.G., Fry, J.C., Weightman, A.J., Parkes, R.J., 2009. Subsurface microbiology and biogeochemistry of a deep, cold-water carbonate mound from the Porcupine Seabight (IODP Expedition 307). Environmental Microbiology 11, 239-257. 